\title{
Contracting between Government and the Voluntary Sector: Where to from Here?
}

\author{
Hilary Stace and Jacqueline Cumming
}

\section{Introduction}

In the 1980s and 1990s public sector management in New Zealand underwent a profound reorganisation. This involved the corporatisation and privatisation of many state assets, with the separation of the roles of funder, purchaser and provider. Non-commercial or 'core' public functions of the state were separated from commercial functions to enable the latter to be contracted out to private organisations, in the pursuit of efficiency and effectiveness (Boston, 1995).

A feature of this 'new contractualism' was the creation of a competitive system of service provision based on 'quasi-markets, whereby the market is incorporated into the welfare state, with the state retaining its role as funder but transferring its task as provider to a variety of independent providers in the third sector (which includes private, profit-making businesses and community and voluntary not-for-profit organisations) and state agencies. Services often remain free at the point of delivery and usually no money changes hands between the final user (e.g. pupils, patients, people with impairment) and the provider (schools, hospitals, disability support services), with the funder paying the provider for the services delivered.

In this era some health and social services were already shifting from public to private provision as a result of deinstitutionalisation policies in mental health, aged and psychopedic care, increasing the role of community organisations in the delivery of services throughout $\mathrm{New}$ Zealand. These independent organisations were then well placed to compete for new contracts. But during the reorganisation period and the establishment of 'quasi'-markets, there was a shift for such organisations from grants funding to contracts. A grant is given to an organisation usually with some flexibility as to its use, and reporting requirements may be minimal. A contract is generally put out to competitive tender, prescriptive as to certain required outputs, and has strict compliance requirements.

In spite of further reforms in the health and social services sectors since 1999, contracting remains a major part of the New Zealand public sector, particularly in the delivery of health and social services. However, we believe that the market model is flawed, as it does not take into account or give value to the complexity and motivations of human interactions. This paper reviews some of the problems that have emerged, particularly for the health and social services sector, over the past decade around the mechanics of contracting. It offers some theoretical and practical solutions to these current problems, and presents some conclusions as to how contracting might be improved.

\section{Problems encountered}

It may seem surprising that contracting has become such an issue, when a contract is merely an agreement to exchange obligations, usually for money. Clarifying the obligations, for the voluntary and community sector in particular, should not require lawyers. And although contracts differ from grants, which tend to have less detail, most contracts are in fact commonsense arrangements. They are simply worded and usually work well. Contracting means that costs, volumes and resource use can be clarified, and there is a chance for new providers, such as iwi, to contract where funding is opened up to new agencies. But in practice it can be a very expensive and legally complex process, with the negotiating of even small contracts involving expensive lawyers and many managers, deflecting money from services. If, in the bidding process, providers change, this can mean the loss of good relationships and institutional memory, and even lingering bitterness. As a consequence, services can be overlooked altogether, leaving service users vulnerable. So, ironically, policy 
makers have created a model that in many cases has deflected resources from actual service provision.

\section{Health and disability sector}

In 1993 there was major reform of the health sector, into something along the lines of a 'quasi'-market, with the introduction of increased contracting and competition. Four purchasers were established to buy services for their regions. They held funding for a wide range of services (primary health, secondary and tertiary services; laboratories and pharmaceutical services; disability support and, later, public health services). The World Health Organisation (2004) reviewed the contracting process and lessons learnt in regard to New Zealand health services. The reforms were intended to clarify costs and volumes, improve quality and allow innovation. There were some successes, as new groups took the opportunity to provide targeted services. But success was limited by the lack of real competition between providers (particularly between hospitals), a complex regulatory framework, and an adversarial legal framework with high transaction costs. Monitoring and accountability were variable and affected by market and political environments. The report emphasised that 'good relationships are seen as the key to successful contracting' (WHO, 2004), but this ideal was hindered by power imbalances between purchasers and providers, and by high staff turnover during the restructuring processes.

In 2000 the sector was restructured again into 21 district health boards (DHBs). DHBs hold the funding for a wide range of health and disability support services; they provide many services themselves and they contract for primary health care and community services from private providers. There are concerns from providers, given the dual role that DHBs play as both purchasers and providers, about the contracting model and what it might mean for the ongoing role of private provision (Health Reforms 2001 Research Team, 2003). The picture becomes further complicated for providers as the Ministry of Health retains direct funder status for some services, while 10 government departments, along with ACC, have various responsibilities in relation to disability services.

Over a decade after the initial reforms in the health and disability sector, contracting with government and its agencies is a major issue, especially for the community and voluntary sector. A 2003 survey by the working group of member non-government organisations (NGOs) revealed a range of concerns about their relationships with DHBs, including poor communication, lack of feedback, failure to follow guidelines, and unequal relationships (Ministry of Health, 2003). It was the theme of the April 2006 health and disability sector NGO-Ministry of Health forum (Ministry of Health, 2006). Community Sector Taskforce member Peter Glensor told the forum that 'the system is characterised by greater or lesser degrees of mistrust, complicated processes of auditing and monitoring, enormous transaction costs for both funders and providers, and a lingering suspicion of malfeasance' (Glensor, 2006, p.3).

Recent research, such as that by Amohia Boulton on the Maori experience of contracting in mental health, indicates that the current system is also not working for Maori. The contracting model does not take into account Maori kaupapa, or ways of working, and as the relationships required are more complex than standardised interactions between provider and client, providers are giving a great deal of voluntary time to meet the needs of tangata whaiora ('people seeking wellbeing') (Boulton, 2005). The area of culturallyappropriate services requires much more attention.

\section{Political responses}

There have been several attempts to address these issues. The 2001 Statement of Government Intentions for an Improved Community-Government Relationship, led by Helen Clark as prime minister and Steve Maharey as minister responsible for the community and voluntary sector, commits the government to 'building strong and respectful relationships with the community sector', with the state as 'facilitator of a strong civil society' (Clark and Maharey, 2001). This commitment was formalised with the sector the following year in the Framework for Relations between the Ministry of Health and Health/Disability NGOs (Ministry of Health, 2002), and in December 2003 Treasury revised its Guidelines for Contracting with Non-Government Organisations for Services Sought by the Crown to reflect this agenda.

An MMP environment (following the introduction of mixed-member proportional representation in 1996) creates a delicate balance of political power. Opposition parties recently used their numbers on the social services select committee to call for an inquiry into the 
provision of services for disabled people (Social Services Select Committee, 2006). Breakdown, inadequacy or manipulation of the contracting relationship is at the heart of this inquiry. The media attention given to problem cases can also be damaging, especially when disagreements between funders and providers stem from complex situations and different views about how the problems may have arisen.

But, in spite of various government initiatives, the system is clearly not working well. As contracting involves service provision to sometimes vulnerable people, and a great deal of taxpayer money, it is important to get it right. It may simply be that more emphasis needs to be put on basic human skills such as relationship development, common sense and trust, which have been overlooked in the enthusiasm for audit and compliance. A change of mind-set is required to emphasise the paramount needs of the service user, supported by strong and interconnected processes.

\section{Ways forward}

Radical change is unlikely and unrealistic, but there are many foundations of the current system that could be built on, by an approach combining theory and practice.

\section{Agency and stewardship theory}

Cribb's (2006) contribution to a recent Policy Quarterly, framing the current contracting system in the voluntary sector in terms of agency and stewardship theory, provides a useful benchmark in this discussion. Agency theory is the underlying philosophy of the contracting model that developed in New Zealand in the late 1980s, as expressed in the Public Finance Act 1989. Agency theory is based on an assumption that people are self-interested and motivated to maximise their own advantage. Principals use contracts to delegate tasks to agents, who must be carefully monitored to ensure that they undertake the task with maximum efficiency and do not abuse the system. Inevitable aspects of the system are goal conflict between principal and agent; information asymmetry, or different levels of knowledge; and moral hazard, whereby the agent will try to outwit the principal, leading to adverse selection when principals contract with agents who are not up to the task. Guarding against these requires a great deal of enforced legal compliance.

However, in her research with community organisations
Cribb found that reality defied the model. She saw that people in the organisations placed a strong emphasis on their relationships with their clients, rather than on the compliance requirements set out in the contract. Cribb argued that while these requirements are there to ensure high standards, in reality 'contracting and funding agreements with government agencies were seen to be driving down standards of care' (Cribb, 2006, p.12).

Cribb instead offers the theory of stewardship, which relies on goal alignment and a relationship of trust, and recognises altruism, whereby people work for the good of the organisation rather than their own financial gain. The attention to shared goals means less emphasis is required on auditing and monitoring.

The agency-theory foundations of the contractual model which replaced the previous grants-based system have been summarised as follows:

A central policy department advised the responsible Minister on the services required by the Crown. The Minister purchased the required services as 'outputs' from the department itself, or from a third party ... The policy department monitored the delivery of the required services under a purchase contract. (Buchanan and Pilgrim, 2004, p.4)

The 1999 election of the Labour-Alliance coalition government signalled a change from agency theory but not from the contracting process itself, which was by then entrenched. Government has developed various strategies since 1999 to improve relationships and capacity-building. The 2004 amendment to the Public Finance Act reflected the desire for a stronger governance relationship between government and crown entities; public service standards for public resources; and managing for outcomes rather than outputs.

However, in a June 2006 paper, Robert Buchanan of the Office of the Controller and Auditor-General replied to Cribb's call for a move from agency to stewardship theory. He advised that the Office of the Controller and Auditor-General has 'advocated a riskbased approach to procurers, as one means of reducing transaction and compliance costs and ensuring that the available monitoring resources are used effectively and efficiently' (Buchanan, 2006, p.11). He suggested that promotion of stewardship was 'simplistic since the notion of stewardship already underlies not only 
public service ethics but also the policy of having legally enforceable obligations in respect to resources that pass from one sector to another ... the fact that a contract is legally enforceable does not mean that the relationship as a whole should be characterised by a mentality of enforcement and compliance' (Buchanan, 2006, p.11).

It should also be noted that contestable funding, a policy which sits more easily with agency theory than with stewardship theory, is now compulsory. This follows a 2005 complaint by an opposition MP about the Ministry of Health procurement and contract management processes, under which former employees were winning non-contested contracts. This led to another report from the Controller and Auditor-General and the end of sole-provider emphasis in procurement (Office of the Controller and Auditor General, 2005). The problem remains: how to fit compulsory contestability into a model consistent with the government's frameworks?

\section{Treasury guidelines}

Treasury's Guidelines for Contracting with NonGovernment Organisations for Services Sought by the Crown, updated in December 2003, provide a comprehensive template and reflect the government's wish for a good working relationship with the sector. The guidelines state that:

- Services purchased through contracts and other types of funding relationships should contribute to the achievement of Government outcomes and objectives.

- Contracting should reflect the needs of the ultimate users or recipients of the service.

- Contracts should provide appropriate accountability for public money.

- Contracts should represent value for the public money.

- The quality of service delivery will usually be of central importance.

- The Crown and its organisations should act in good faith.

- Government agencies should understand the nature of the organisations they and the Crown contract with.
Contracting and funding relationships with the community organisations should be consistent with the relationship the Government seeks to have with the community and voluntary sector. This implies:

- Recognising the objectives of both parties.

- Respecting the autonomy of the voluntary sector.

- Communicating in an open and timely manner.

- Working constructively together.

- Recognising the responsibilities of each party to its stakeholders. (Treasury, 2003)

There are different types of contracting or funding arrangements, but the above principles of good contract management are the same across the entire contract cycle.

Notwithstanding this, it is apparent from media reports, and anecdotally from NGOs, that many government contract managers and providers are not following Treasury's guidelines. Several providers at the April 2006 NGO-Ministry of Health forum complained of obstructive contract managers who do not answer phone calls or emails, or pay on time. This is part of the 'moral hazard' identified by agency theory, and is out of step with the ethics-based public sector stewardship that the Office of the Controller and Auditor-General advocates.

In light of these issues, it might be wishful thinking to suggest that it may be time for government agencies to look at whether contracts are always necessary. But, why have a long contract when a short letter setting out key issues will do? These processes should be straightforward and understandable to the people, often volunteers, involved in the community, voluntary, health and disability sectors. Responsible adults are usually well motivated to provide the required services. How, then, to move past the adversarial, low-trust practices that characterise contract theory and contracting?

Cribb's stewardship theory provides a good basis for analysis. Although it is already implied in the Treasury guidelines and Attorney-General's recommendations, there needs to be more emphasis on stewardship principles by those in the contracting partnership.

\section{Good faith}

Good faith is a key aspect that is obliterated by the assumptions underpinning agency theory, yet it is 
central to the Treasury guidelines. Good faith recognises that people can exercise common sense, behave well and agree on what needs to be achieved. It involves honesty and fairness, transparent and democratic processes, accurate records, and the disclosure of relevant information in timely ways with 'no surprises'. Listening to others, taking account of what they say and looking for ways to make the agreement work are vital. Good faith is the basis of good relationships, which, as the WHO report emphasises, are the key to successful contracting (WHO, 2004). Basic communication skills are very important.

However, despite the best of intentions, problems and conflicts may still arise, such as non-performance by one side. Contracts are often ended by agreement, and this is part of good relationship management. But perhaps some kind of contracting ombudsman is needed to mediate in extreme situations?

\section{Collaboration and networking}

Sholom Glouberman is a Canadian-based health philosopher who writes on entrenched attitudes and practices in health care. His theories apply aptly to the contracting process. He calls for more emphasis on the human skills of networking, and collaborations across the sector (Glouberman et al., 2006). Policy makers have confused these complex human interactions with complicated mechanical procedures requiring merely a definitive manual. However, there is not a single formula or solution for such interactions, and local conditions require local responses. The need for stability in the health system is paramount and making 'small changes in stable environments to build on local strengths', such as 'rewarding and increasing the profile of programs where good collaboration is evident', will be more successful than attempts at restructuring (Glouberman et al., 2006, p.10). Effective collaborations are characterised by the parties treating each other as equals, having a well-rounded acquaintance, sharing a common purpose and being emotionally intelligent (Glouberman, 2006).

These ideas have been taken up in the New Zealand context by Gray Southon and others, who suggest that improved networking between health professionals, policy makers and community groups is the key to the future of health services (Southon et al., 2005). The health reforms of the 1990s emphasised hierarchical systems as a means of ensuring power and control. But networks 'handle knowledge, support expertise and deal with complexity in ways that hierachies are unable to' (Southon et al., 2005, p.317).

Human networks are relationships, which, by combining knowledge and perspectives, can solve complex issues, including those discussed here. It may be significant that a recent American book on social intelligence and human relationships (Goleman, 2006) is a bestseller.

\section{Allies in emancipation}

Expertise from the disability sector provides another theoretical approach. O'Brien and Sullivan (2005) suggest that in order for professionals to become 'allies in [the] emancipation' of disabled people they need to shift from the notion of providing services to that of being of support. If this capacity and empowerment model is applied to the contracting process, then the lived experience of the target population, the recipients of service, will become the sector's most valuable resource. Contract management and evaluation will be enhanced by the representation of target populations on boards, in workplaces and in decision making positions as valued 'bullshit detectors'. It is heartening, for example, that the Disability Services Directorate of the Ministry of Health has recently set up a consumer consortium.

\section{Government initiatives}

There are indications that government agencies themselves are looking at how the system can be improved, through mechanisms such as longer-term contracts, to ensure that more money is available for service provision and less is required for negotiation and compliance. With 16,500 live contracts in the Ministry of Health alone, there is much at stake. At the October 2006 health and disability sector NGOMinistry of Health forum the minister acknowledged that contracting is one of the major challenges facing NGOs, and, as one step in addressing this, an NGO perspective has been added to the ministry's staff training on contracts (Hodgson, 2006).

The current Ministry of Health contract document emphasises 'relationship principles', including integrity, open communication and valuing people (Ministry of Health, undated, p.3). An example of this came in a recent 'relationship building briefing' from a Ministry of Health contract manager to an NGO board hoping 
to develop services for its members through ministry contracts. He explained that contract managers are looking for indicators such as quality information, an involvement with and focus on Maori and Pacific peoples, and robust governance-management systems in the NGO itself, with clarity about who speaks for the organisation in its relationship with the ministry. If the NGO did not have the expertise in a particular area, such as Maori (a ministry priority), a lead agency partnership based on memoranda of understanding was one option. The ministry, however, would have to be assured that all parties met the contractual requirements. This simple initiative, aimed at helping the NGO to get it right at the beginning of the process, shows what a difference relationship building can make. Many of the current problems have arisen because, under the agency theory basis of contractualism, these skills have been neither valued nor encouraged.

The Ministry of Social Development (2006) has recently undertaken an action research project entitled 'Funding for Outcomes - Integrated Contracts', which aims to integrate an organisation's various contracts in order to reduce compliance and transaction costs and provide more effective targeting of resources. One of its attractions is that it is a 'kitset' of contract elements rather than a 'one size fits all' model.

The Disability Services Directorate of the Ministry of Health is also looking at options to enhance accountability and transparency, and achieve more stability, security and power for vulnerable service users. Some sort of person-centred and pooled funding, and more emphasis on outcomes such as wellbeing in the home, rather than the purchasing of outputs (in which housework may be included, but not shopping), are possibilities. There is some interest in the Western Australian local area coordination system, whereby a local coordinator (not a service provider) works with people and their families to plan, select and receive services. This embodies the networking advocated by Glouberman and others. The monopsonistic position of the New Zealand public sector is one reason why the market model has not worked. For example, the Disability Services Directorate of the Ministry of Health is the sole purchaser of many disability services. The Office of Disability Issues (part of the Ministry of Social Development) is reviewing the New Zealand situation through the perspective of the New Zealand Disability
Strategy, and has uncovered similar concerns around the fragmentation of the current contracting system.

\section{NGO suggestions}

Glensor (2006) provided another practical example at the April 2006 NGO-Ministry of Health forum, suggesting a model that is based on outcomes and relationships, requires no lawyers, and places greater emphasis on the personal accountability of the people involved. He described a 1998 situation in which a large public health grant was given by the minister of health to Health Care Aotearoa, which then invited groups to apply for this funding when they were ready. Applicants were tested against some mutually agreed criteria, without competitive tendering. Each proposal was tested by a group of members who had personal experience in the area. In this way they addressed the problem of inappropriate services, and in the absence of competition they addressed the predominant lowtrust, often adversarial, agency model. The process also accommodated different kaupapa, as those wanting to provide a service proposed one appropriate to the needs of their local population. In these days of the New Zealand Disability Strategy, the New Zealand Health Strategy, the Maori Health Strategy and the various other strategies emphasising outcomes rather than outputs, a much greater flexibility around kaupapa is required.

At the October 2006 NGO-Ministry of Health forum questions were raised about whether 'not for profit' organisations should have fewer compliance requirements than 'for profit' organisations. Some expressed concern at the profit making of organisations, while others complained that contracts provide insufficient money to pay workers properly and fulfil compliance requirements at the same time. There are still concerns that a great deal of administration time is spent on 'request for proposals' (i.e. contract bid) preparation, delivery and evaluation, at the expense of the provision of services to members.

\section{Charities Act}

There is currently another element in this mix which is causing concern over contract compliance in the community and voluntary sector, and in the media: the legal requirements of the 2005 Charities Act. Voluntary registration of charitable organisations with 
the new Charities Commission set up as a result of the act begins in February 2007. As this is an untried process, many NGOs are unsure how this will affect their charitable status and integrity as contract holders. Some appear to have centralised their administration structures, while others have strengthened their regions. The Charities Commission has a potentially significant role in clarifying and resolving issues around contracting in this sector.

\section{Conclusions}

The contracting-out of goods and services has now been a central feature of the New Zealand governmental system for almost two decades, and is well entrenched. But it is not working well in many situations, possibly because the processes and goals are not clearly understood by some funders and providers. It appears from various government statements that New Zealand policy is currently in a transition between the principles of agency theory and stewardship theory, but is still confused by continuing legal requirements for contestability.

So what are the keys to successful contracting? If NGOs, the government and government agencies are working together towards the agreed policy outcome of a healthy, inclusive and interdependent society, contracting should be a straightforward and understandable part of the process, not something separate and legally obscure. The key is building good relationships throughout the sector - between the funders, providers and service users and within all the organisations involved - based on common sense, good faith and accountability. It also involves having robust governance-management systems, and knowing what the differing responsibilities are; using the same language; keeping good records; understanding what is required and doing it; dealing with problems early rather than letting them fester; keeping to a timeframe; and constantly reviewing, reflecting, learning and improving.

There are many examples of good practice on an individual and agency level. Practices can also be borrowed from other government agencies, such as the publicly accessible audits of the Education Review Office. More provision for input from service users would be valuable in performance appraisal and evaluation. Respectful mutual communication would also help.

Contracting can be complex, and problems can seem intractable when parties are stuck. But contracts do not have to be so difficult. Even children can understand the basics of contracting, when they enter into an agreement with their parents, such as with a star chart. Successful star chart contracting would involve the basic Treasury guidelines in a form that even a child can understand.

Other aspects of contracting also require work, such as taxation reform to encourage philanthropy, or the need for agreed guidelines around lobbying and advocacy. Both are currently under policy review. Developing public agreement on shared values such as generosity, trust, flexibility, diversity and empowerment would enhance the contracting environment. However, if more emphasis is placed collectively on building and successfully managing relationships, then almost anything is possible.

\section{References}

Boulton, A. (2005) 'Provision at the Interface: the Maori experience of mental health contracting', $\mathrm{PhD}$ thesis, Massey University

Boston, J. (ed.) (1995) The State Under Contract, Wellington: Bridget Williams Books

Buchanan, R. (2006) 'Walking the line: contracting and the public-private divide', paper prepared for the LexisNexis government contracting conference, Wellington, 19 June

Buchanan, R. and C. Pilgrim (2004) 'Transparency and accountability in government decision making: devolved service delivery', paper prepared for the Conferenz 6th annual public law forum

Clark, H. and S. Maharey (2001) Statement of Government Intentions for an Improved CommunityGovernment Relationship, Wellington: NZ Government Executive

Cribb, J. (2006) 'Agents or stewards? Contracting with voluntary organisations', Policy Quarterly, 2, (2), pp.11-17

Glensor, P. (2006) 'The future of contracting: alternative models to competitive tendering', presentation to the health and disability sector NGO-Ministry of Health forum, Auckland, 11 April, www.ngo.moh.govt.nz/ngo, retrieved 20 June 2006

Glouberman, S. (2006) www.healthandeverything.org Glouberman, S. et al. (2006) 'Entrenched health care 
practices and complex systems', Australian Health Review, 30 (1) February, pp.7-11

Goleman, D. (2006) Social Intelligence: the new science of human relationships, New York: Bantam

Health Reforms 2001 Research Team (2003) Interim Report on Health Reforms 2001 Research Project, Wellington: Health Services Research Centre, School of Government, Victoria University of Wellington

Hodgson, P. (2006) Address to the health and disability sector NGO-Ministry of Health forum, 19 October, www.beehive.govt.nz, retrieved 28 October 2006

Ministry of Health (undated) 'Agreement between Her Majesty the Queen in right of her government in New Zealand (acting by and through the Ministry of Health) and "Provider Name", www.moh.govt.nz, retrieved 4 July 2006

Ministry of Health (2002) Framework for Relations between the Ministry of Health and Health/Disability Non-Government Organisations, Wellington, www. moh.govt.nz

Ministry of Health (2003) 'Survey of NGO relationships with DHBs - November 2003', www.mch.govt.nz, retrieved 25 October 2006

Ministry of Health (2006) Health and disability sector NGO-Ministry of Health forum, 12 April, www.moh. govt.nz, retrieved 12 June 2006

Ministry of Social Development (2006) Funding for outcomes - integrated contracts, www.msd.govt.nz/workareas, retrieved 17 July 2006

O'Brien, P and M. Sullivan (eds) (2005) Allies in Emancipation: shifting from providing service to being of support, Melbourne: Dunmore

Office of the Controller and Auditor General (2005) Inquiry into the Ministry of Health's contracting with Allen and Clarke Policy and Regulatory Specialists Limited, www.oag.govt.nz/2-0-5/moh/summary.htm, retrieved 3 July 2006

Social Services Select Committee (2006) 'Inquiry into the quality and care of services provision for disabled people', www/clerk.parliament.govt.nz/Programme/ Committeees/Submissions/, retrieved 24 June 2006

Southon, G., R. Perkins and D. Galler (2005) 'Networks: a key to the future of health services', Australian Health
Review, 29 (3), pp.317-26

Treasury (2003) Guidelines for Contracting with NonGovernment Organisations for Services Sought by the Crown, www.treasury.org.nz/publicsector/ngo/default. asp, retrieved 1 April 2006

World Health Organisation (2004) Contracting for Health Services: lessons from New Zealand, Geneva: World Health Organisation

Hilary Stace is a research assistant in the Health Services Research Centre, School of Government, Victoria University of Wellington. She has been a member of many community organisations, is on the board of a medium-sized nongovernmental organization and is a member of the Ministry of Health's Disability Services Directorate Consumer Consortium. She recently won Health Research Council funding for $\mathrm{PhD}$ research on autism in New Zealand.

Jacqueline Cumming is Director of the Health Services Research Centre of the School of Government, Victoria University of Wellington. She has many years of experience as a policy analyst, and in health economics, health policy and health services research. She was involved in reviewing the New Zealand experience of contracting in the health and disability sector for the World Health Organisation in 2004. She is continuing to conduct research on contracting processes. 